\title{
Features of meteoric diagenesis in coquinas of Morro do Chaves Formation (Barremian-Aptian of Sergipe-Alagoas Basin)
}

\author{
João Paulo Porto-Barros ${ }^{1 *}$ (D), Ighor Dienes Mendes² (D, Patrick Führ Dal’ Bó' (1)
}

\begin{abstract}
The Morro do Chaves Formation (Barremian-Aptian of the Sergipe-Alagoas Basin) presents a sedimentary succession of approximately $150 \mathrm{~m}$ of thickness, composed of coquinas. Despite the sedimentological, stratigraphic, and petrophysical studies developed in coquinas, the general understanding of the relationship between sedimentary processes and meteoric diagenesis is not clear. The aim of this study is to recognize and understand the features of meteoric diagenesis in bioclastic from a well core drilled at Atol quarry. The core is composed of calcarenites and calcirudites interbedded with sandstones and shales. Taphonomic signatures show a low degree of physical alteration, without shells in life position. The main features related to meteoric diagenesis are bioclasts with bioerosive macrostructures (Caulostrepsis isp. and Oichnus isp.) and destructive micritization process. This was the main alteration process identified in the bioclasts and occurs throughout the coquinas interval and, in some beds, it was possible to distinguish three different stages of micritization. The differentiation of the stages results from different periods of variation of water depth, intensity of microorganisms attack, time of alteration, and variations in siliciclastic input. Additionally, one interval exhibits extremely micritized shells, curved fissures, and carbonate nodules, interpreted as having been deposited and subsequently altered in a palustrine environment.
\end{abstract}

KEYWORDS: meteoric alteration; micritization; bioclasts; Atol quarry; Morro do Chaves Formation.

\section{INTRODUCTION}

Coquinas are very valuable sources of paleontological, paleoecological, and sedimentological data (Kidwell et al. 1986, Kidwell and Holland 1991, Simões et al.2000). Coquinas are defined, according to Kidwell et al. (1986), as "any dense accumulation of hard parts of biogenic origin, independent of taxonomic composition, preservation state or degree of post-mortem modification". They can be composed of fragmented or whole shells, or a mixture of them (e.g., Simões and Kowalewski 1998, Best and Kidwell 2000, Fürsich and Pandey 2003, Neves et al. 2010, Ponciano et al. 2012).

The preservation of the bioclasts that compose coquinas in the geological record are related to different parameters: physical (water energy and depth), ecological (predation and bioturbation), biostratinomic (bioerosion, dissolution, and abrasion), and diagenesis (Kowalewski et al. 1994, Zuschin et al.2003). The diagenetic processes have a huge influence in the shells preservation, especially when exposed to the surface (meteoric environment), which results in significant changes

${ }^{1}$ Universidade Federal do Rio de Janeiro - Rio de Janeiro (RJ), Brazil. E-mails: jp@geologia.ufrj.br, patrickdalbo@geologia.ufrj.br

${ }^{2}$ Instituto de Biologia, Universidade Federal do Rio de Janeiro - Rio de Janeiro (RJ), Brazil. E-mail: igpaleo@ufrj.br

${ }^{*}$ Corresponding author.

(C) 2020 The authors. This is an open access article distributed under the terms of the Creative Commons license. in the carbonate material (Tucker and Wright 1991), sometimes culminating in the complete elimination of the shell.

Although physical and chemical factors influence preservation, deposits formed of coquinas are relatively common in the geological record from several examples - e.g., Vectis Formation, Lower Cretaceous (Radley and Barker 2000); Lagoa Feia Group, Lower Cretaceous (Muniz 2013); bioclastic accumulation of coastal plain of Rio de Janeiro State, Holocene (Castro 2009, Porto-Barros et al. 2017), and Hamelin Pool, Holocene of Shark Bay (Playford et al. 2013).

In this study we combine sedimentological and taphonomical data to describe and interpret the changes associated with meteoric alteration in the shells that compose the coquinas of the Morro do Chaves Formation (Barremian-Aptian), Sergipe-Alagoas Basin, northeastern Brazil. This succession is well known for its huge accumulation of coquinas and is perhaps one of the best examples to study the coquinas succession located onshore along the entire South Atlantic coast (Thompson et al. 2015). Nevertheless, information on features of meteoric diagenesis occurring in those shells is only briefly discussed in few studies (e.g., Belila 2014, Tavares et al. 2015 ), thus reducing the possibilities of a complete evaluation on the importance and extent of the meteoric alteration in the paleoenvironmental analysis. Our goal is to recognize the complete array of features of meteoric diagenesis in a coquinas interval that exhibits a complex organization of the porous space generated by overlapping phases of diagenetic alteration. 


\section{GEOLOGICAL SETTING}

The Sergipe-Alagoas Basin is located in the Northeast Brazil in the Sergipe and Alagoas states (Fig. 1), with an area of approximately $34,600 \mathrm{~km}^{2}\left(12,000 \mathrm{~km}^{2}\right.$ onshore and 22,600 $\mathrm{km}^{2}$ offshore) (Lana 1990). The basin consists of regional half grabens dipping $10-15^{\circ}$ to the southeast (Koutsoukos et al. 1991, Koutsoukos and Bengtson 1993), formed as a result of the continental separation between South America and Africa (Asmus and Baisch 1983). The basin extends $350 \mathrm{~km}$, elongated in the NE-SW orientation and $35 \mathrm{~km}$ wide (on average). The offshore part does not have a well-defined limit, but extends beyond the 2,000 $\mathrm{m}$ isobar (Lana 1990). According to Feijó (1994), the Maragogi High separates the basin from the Pernambuco-Paraíba Basin (northeast) while the Vaza-Barris fault system separates it from the Jacuípe Basin (southwest).

The basement consists of Precambrian metamorphic rocks of the Sergipano belt (Feijó 1994) and granitic rocks of Alagoas Pernambuco batholith (Campos Neto et al. 2007). According to Feijó (1994), the sedimentary record of the Sergipe-Alagoas Basin is subdivided into five depositional sequences: Permo-Carboniferous (sag); Jurassic-Early Cretaceous (pre-rift); Hauterivian and Barremian (rift); Aptian (post-rift) and Albian-Pliocene (drift). The basin filling is composed of 20 formations grouped into five lithostratigraphic groups: Igreja Nova, Perucaba, Coruripe, Sergipe, and Piaçabuçu, from Carboniferous to Pleistocene in age. The Morro do Chaves Formation of Coruripe Group represents a coquina interval of the rift sequence (Fig. 2).

The Morro do Chaves Formation is Barremian-Aptian in age (Jiquiá local Stage) and composed of successions of limestones, coquinas, marls, and dolomites, with clastic intercalations (Schaller 1969), developed in shallow and elevated regions of a large rift lake with very low input of terrigenous and high energy conditions (Figueiredo 1981), overlaying the fluvial deposits of the Penedo Formation (Azambuja et al. 1998).

Coquinas are composed of bivalves that lived in shallow oxic waters, whose shells were reworked after their death, accumulating as banks, over-wash fans and beach deposits by periodic storms, with sedimentary transport toward the coast interbedded with sandstones and shales (Azambuja et al. 1998).
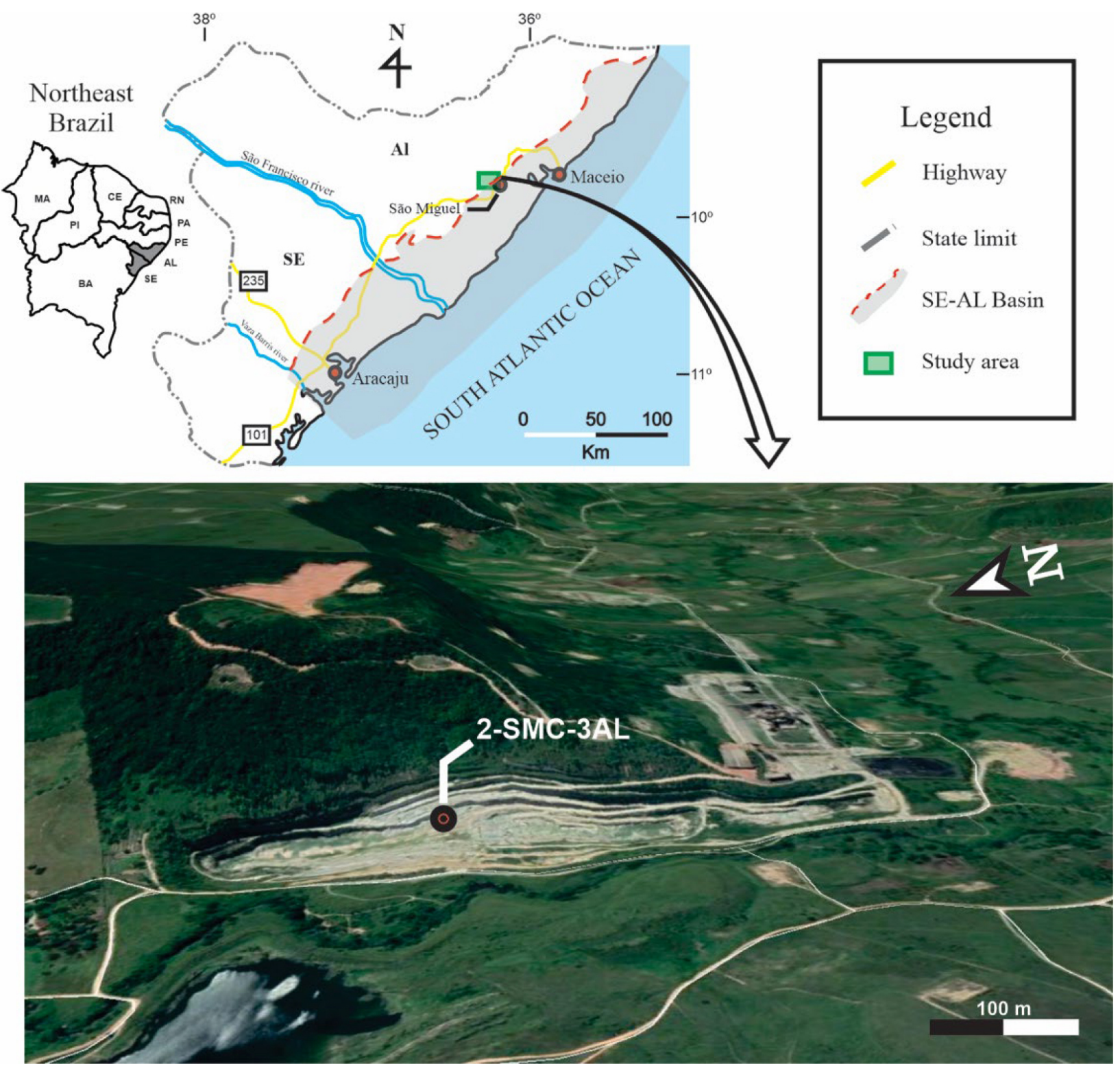

Figure 1. Location of the study area in Atol quarry, São Miguel dos Campos municipality, Northeast Brazil. 


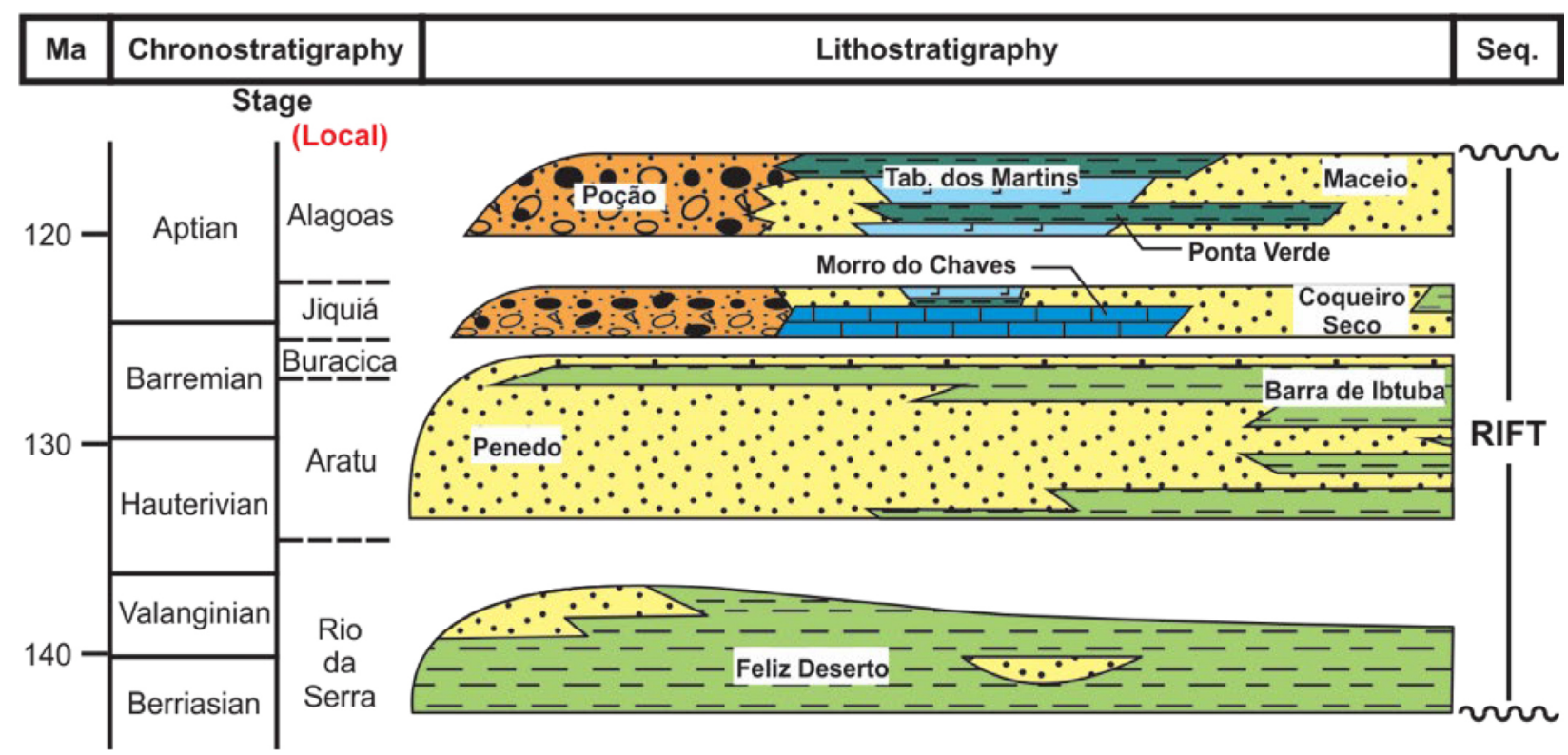

Source: modified from Campos Neto et al. (2007).

Figure 2. Stratigraphic chart of the rift sequence of the Alagoas Sub-Basin with local ages and lithostratigraphic formations.

Morro do Chaves Formation is approximately $150 \mathrm{~m}$ thick. Cycles of coarsening and thickening-upward can be observed in the Morro do Chaves Formation and are interpreted as a variation in the lake level (Tavares et al.2015, Thompson et al.2015).

Mello et al. (1993), based on biological markers and micropaleontological data, idealized a setting for the Lower Cretaceous in the Sergipe-Alagoas Basin, the authors assuming a lacustrine hypersaline system with semi-arid to arid climate, where specific groups of precursors thrived. Moreover, the authors found the ostracofauna of Lower Cretaceous is very similar to that of the coquina sequence of Lagoa Feia Formation (saline lacustrine system), Campos Basin.

\section{MATERIALS AND METHODS}

The material for this study is stored at the Laboratory of Sedimentary Geology, Federal University of Rio de Janeiro, and consists of one well-core 2-SMC-3AL, with $174.50 \mathrm{~m}$ of thickness, drilled in the Atol quarry (9॰45'22”S-36 $\left.9^{\circ} 17^{\prime \prime} \mathrm{W}\right)$, located in São Miguel dos Campos, Alagoas State.

The description of the core was done using the method of facies analysis (Walker 2006) without the use of the facies codification. The description considered lithological properties, percentage of bioclasts, biofabric, and sorting. For the taphonomic analysis of the coquina, six variables were quantitatively evaluated: articulation; fragmentation; abrasion; rounding; microarchitecture; and orientation (Kidwell et al. 1986, Davies et al. 1989, Kidwell and Holland 1991). Colors are described in accordance with the Munsell notation (Munsell 2009).

The taxonomic identification and definition of taphonomic signatures used two samples of coquina collected from outcrops in the Atol quarry. In these samples, bioclasts (whole shells and fragments) were extracted from the matrix using Micro Drill (for mechanical disaggregation) and solutions of sodium hypochlorite 2.0 to $2.5 \%$ and acetic acid ( $4.0 \%$ acidity). The bioclasts were carefully washed with distilled water, in order to avoid more abrasion and dissolution. These two samples are correlated to the lithological intervals of the upper part of the described well core. The specimens in this study were classified according to the paleontological systematics proposed by Carter et al. (2011). Descriptive terminology of shells follows Carter et al. (2012).

Taphonomic attributes were evaluated from 150 randomly selected bioclasts, which were analyzed under stereomicroscope. Each bioclast was compared to an individual of reference (McGlue et al.2010) and classified with different grades: articulation (absent, rare, and common); physical alteration, including abrasion, fragmentation, and rounding (absent, low, and high); preservation of microarchitecture (absent, rare, and high); and orientation (concave-up, concave-down, and high variance).

The intervals with the best preserved shells were macroscopically described in detail on a 1:10 scale, in order to observe features of meteoric alteration, as marmorization, nodulization, pattern of fissures, bioturbation, and grainification (Freytet \& Plaziat 1982). The microscopic description of nine thin sections from this interval were used to the characterization of the micrite envelopes and the micritization process (Bathurst 1975, Kobluk and Risk 1977, Flügel 2004).

The macroscopic description of bioerosion structures were made observing the morphology, orientation, limits, and ramifications (Bromley 1996). In shells with macrobioerosive features, the internal architecture was evaluated using micro-CT images from a computed microtomography equipped with Skyscan Model 1173 High Energy equipment.

\section{RESULTS}

\section{Sedimentology}

The studied well core is composed of coquinas (mainly bivalves and subordinately gastropods and carapace of ostracods) 
interbedded with shales and sandstones. A conglomerate bed at depth between 77.50-79 m marks an important stratigraphic boundary where the shells overlying this bed are better preserved and less recrystallized (Fig. 3 ).

Polymitic conglomerate ( $2.5 \mathrm{Y} 8 / 1$ in color) composed of metamorphic and plutonic clasts, with abundant medium sand matrix. The gravel size clasts are rounded to subrounded, maximum particle size is $3 \mathrm{~cm}$. Matrix poorly sorted composed by quartz.

Sandstone (2.5Y 8/1 in color) (fine to coarse grained) poorly sorted composed of subangular to angular quartz grains with approx. $10 \%$ of fine pebble, fragments of shells, and clasts of metamorphic rock.

Two facies of shales are recognized: greenish shale (10G 8/2 in color) with non-marine ostracods, fish fragments and carbonate concretions, and thinly laminated black shale (N4 in color), with intercalations of very fine sand, composed of ostracods, small carbonate nodules and micritized shells, exhibiting a high organic matter content and a total organic carbon (TOC) up to $3.90 \%$ (Figs. 4A and 4B).

The coquinas are mostly calcarenites and calcirudites (with shell size from $<0.5$ to $3 \mathrm{~cm}$ ), densely-packed with $60-70 \%$ of shells, and few beds with less than $40 \%$ of shells. Crystalline intervals occur where coquina beds are very cemented with many stylolites that make the identification of shells very difficult (Figs. 4C, 4D and 4E).

The matrix in the bioclastic beds are composed of less than $30 \%$ of terrigenous sand, fine- to coarse-grained, subangular to angular, poorly sorted, composed of quartz, smashed intraclasts and clasts of granite, gneiss and metamorphic rocks.

Through macroscopic description, it was possible to distinguish different beds of coquina.

- Densely packed coquina composed of $60 \%$ of shells (maximum size $3.5 \mathrm{~cm}$ ) with fine sand matrix $(30 \%)$, micrite $(<5 \%)$ and $1 \%$ of metamorphic clasts $(2 \mathrm{~cm})$. Moderately sorted, pervasive cementation, and many stylolites. Rare articulated shells, concave-up orientation, low fragmentation, absent rounding, low abrasion, and low preservation of microarchitecture. Micrite occurs punctually and on the border of some shells;

- Densely packed coquina composed of $50 \%$ of shells (maximum size of $2 \mathrm{~cm}$ ) with mud and fine sand matrix (30\%), micrite (5\%), intraclasts (1\%), and metamorphic clasts (1\%). Poorly sorted, pervasive cementation and many stylolites. Absent articulated shells, concave-up orientation, high fragmentation, low rounding, high abrasion, and absent microarchitecture. Micrite occur in discontinuous envelopes;

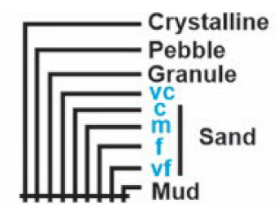

Depth $(m)$

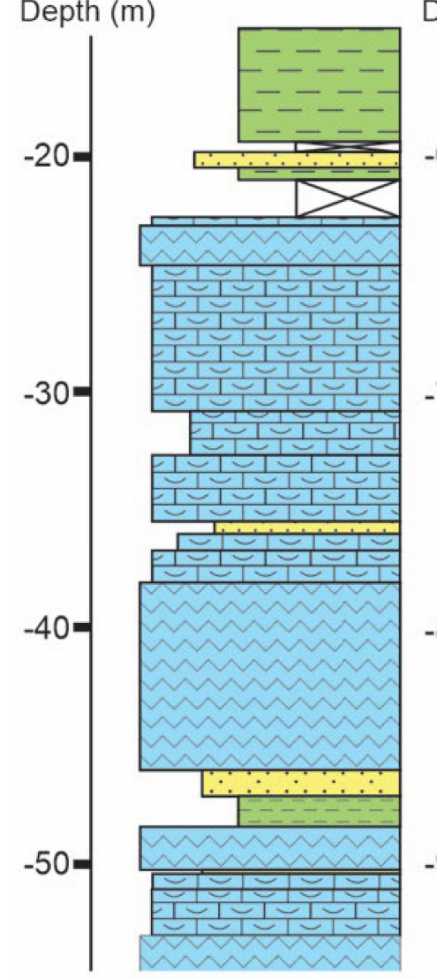

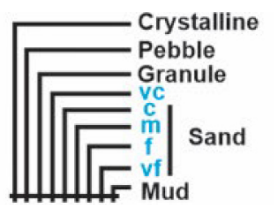

Depth $(\mathrm{m})$

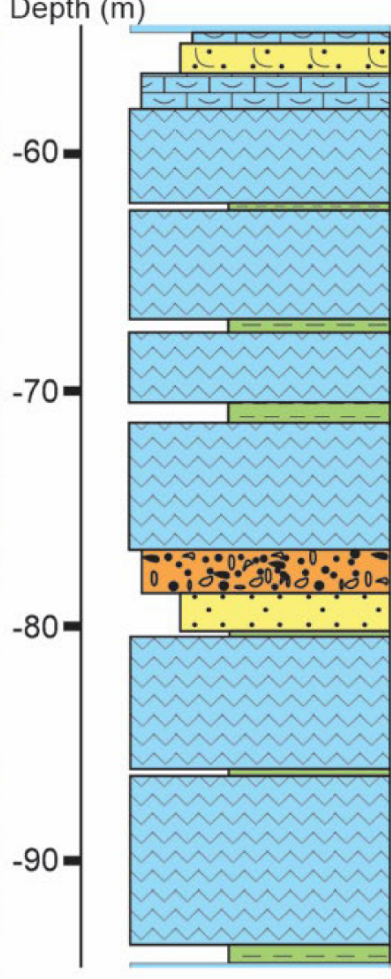

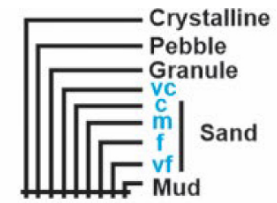

Depth $(m)$

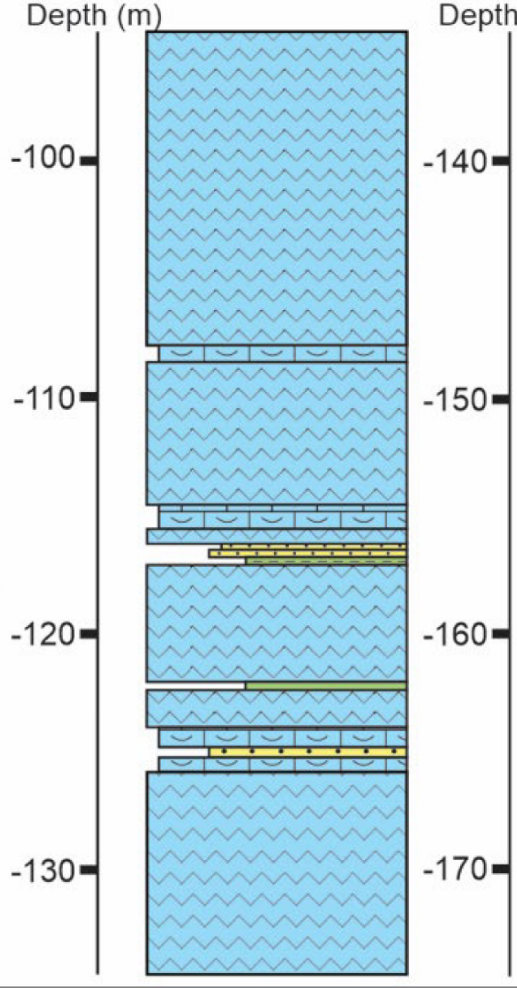

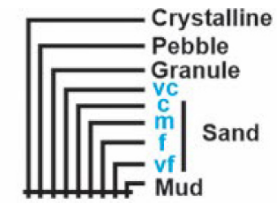

(m)

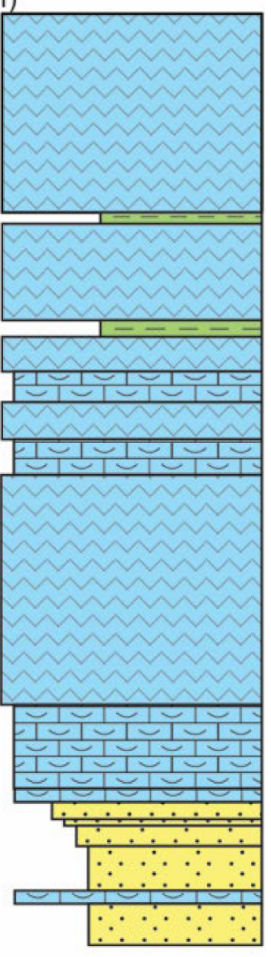

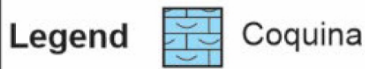

Crystalline

Figure 3. Core description of the well 2SMC-3AL, showing the stratigraphic succession of the Morro do Chaves Formation in the well core. Vertical scale 1:250. 

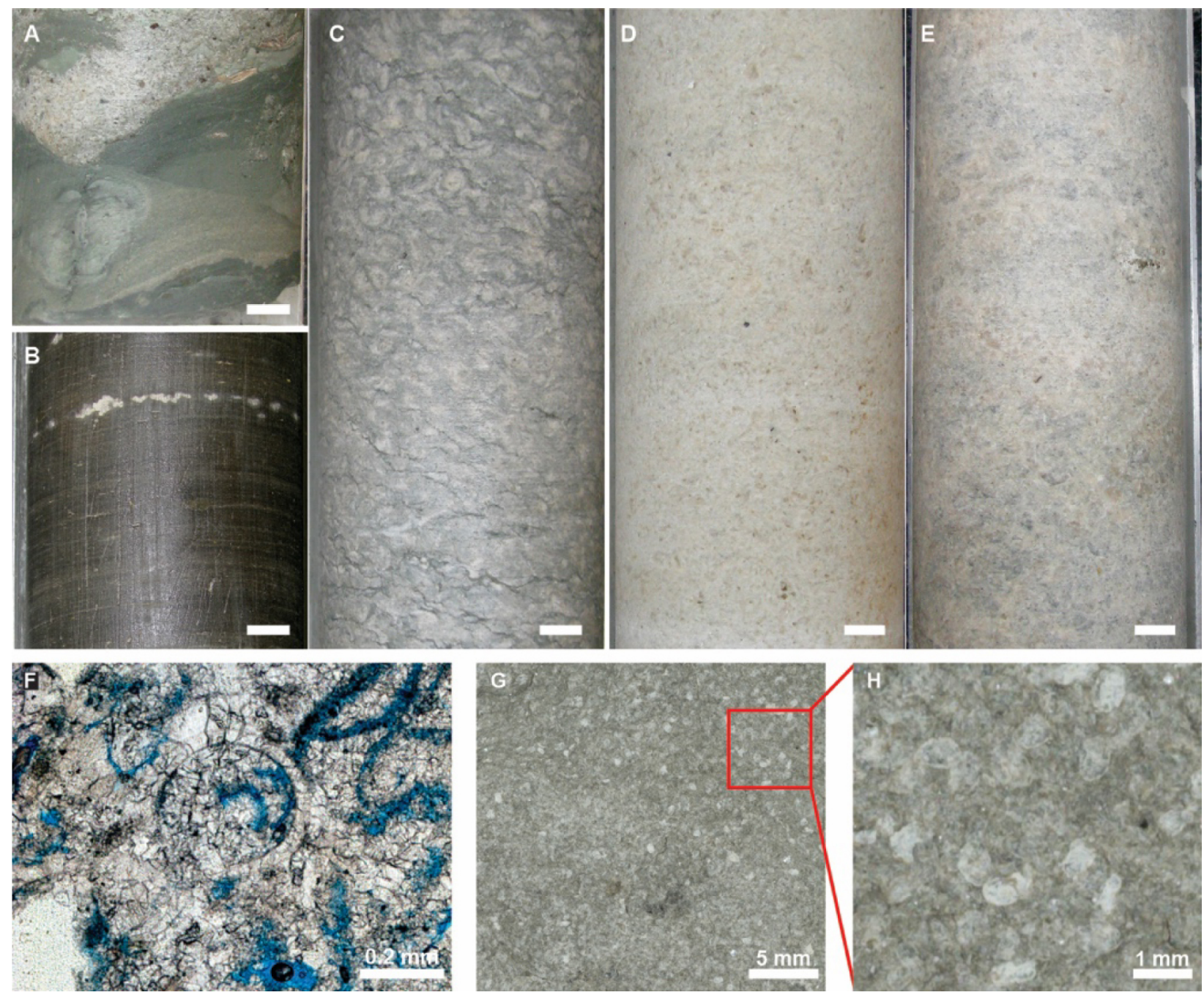

Figure 4. (A) Green shale with intercalations of $\mathrm{cm}$-thick laminae of fine sand; (B) black shale with small carbonate nodules and micritized shells; (C) densely-packed coquina with whole shells; (D) densely-packed coquina with fragmented shells; (E) very cemented denselypacked coquina; (F) photomicrography of gastropod $46.10 \mathrm{~m}$ of depth; $(\mathrm{G})$ articulated carapace of ostracod of black shale; $(\mathrm{H})$ red square highlights ostracods. Scale bar $1 \mathrm{~cm}$.

- Densely packed coquina composed of $60 \%$ of shells (maximum size of $1 \mathrm{~cm})$, matrix of mud and fine sand $(15 \%)$ and micrite $(<5 \%)$. Moderately sorted and intense cementation. Absent articulated shells, concave-up orientation, high fragmentation, low rounding, high abrasion, and low-preserved microarchitecture. Micrite occur in thin continuous envelopes;

- Densely packed coquina composed of $60-70 \%$ of shells (maximum size of $1.0 \mathrm{~cm}$ ), with mud and fine sand matrix (10\%) and micrite (5\%). Poorly sorted and pervasive cementation. Rare articulation of shells, concave-up orientation, high fragmentation, absent rounding, high abrasion, and low preservation of microarchitecture;

- Densely packed coquina composed of $60 \%$ of shells (maximum size of $1 \mathrm{~cm}$ ) with mud and sand matrix (15\%). Intense cementation. Absent articulation, concave-up orientation, low fragmentation, low rounding, low abrasion, and low preservation of microarchitecture;

- Densely packed coquina composed of 50-60\% of shells (maximum size of $1 \mathrm{~cm}$ ) with matrix of very fine muddy sand (15\%) and intraclasts of $2 \mathrm{~cm}$ in diameter. Intense cementation. Common articulation of shells, convex-up orientation, low fragmentation, low rounding, low abrasion, low preservation of microarchitecture. Thin and discontinuous envelopes of micrite envelopes.

\section{Taxonomy}

The studies devoted entirely to invertebrate taxonomy from the Morro do Chaves Formation were Duarte (1936), Borges (1937) and Oliveira (1937). They listed freshwater and marine bivalve taxa without stratigraphic control from sites currently lost. However, they relate to specimens to the Morro do Chaves Formation. Here, such taxonomy is not used as a reference due to its outdating and loss of valuable data for comparison purposes.

The bioclasts of Morro do Chaves Formation are composed of different recrystallized shells of bivalves and gastropods and carapace of ostracods (Figs. 4F, 4G and 4H). However, gastropods shells and carapace ostracods had their morphology obliterated by the diagenesis process. Although with better 
morphological preservation than the other invertebrates, the bivalves were identified only at the superfamily level.

Class BIVALVIA Linnaeus, 1758

Clade EUBIVALVIA Carter, 2011

Order CARDITIDA Dall, 1889

Superfamily CRASSATELLOIDEA Férussac, 1822

CRASSATELLOIDEA family, genus et sp. indet.

Fig. 5

Description. Small to medium sized shell; subtrigonal to ovate outline; external sculpture vanishing; distinct lunule; beak prominent, flattish, slightly incurved, prosogyrate, situated a little in advance of the midlength; hinge lucinoid, right and left valves with two cardinal teeth and two sockets. The internal features are not well preserved on the molds, but a palial line integripalliate can be faintly seen in some specimens. Larger shell dimensions: length $20 \mathrm{~mm}$., mean $10.56 \mathrm{~mm}$. ( $\pm 3,444)$; height $17 \mathrm{~mm}$, mean $9.81 \mathrm{~mm} .( \pm 2,509)$.

Remarks. Carefully, the arresting morphological spectrum, regarding taxonomic attributes, allows to include the described specimens in the Superfamily Crassatelloidea Férussac, 1822. Mainly due to the presence of cardinal teeth closely related to those found in Crassatellidae, Astartidae and Carditidae (for comparisons see Stilwell 1998, Gardner 2005, Jaitly and Mishra 2009).

\section{Taphonomy}

The results showed the bioclasts are predominantly non-articulated, more than $75 \%$ of the described beds have a rare occurrence of articulated bioclasts (Fig. 6A); more than $85 \%$ of bioclasts have some degree of fragmentation (i.e., low and high) (Fig. 6B); rounded shells are not common with $55 \%$ of the bioclasts, showing absence of rounding and $38 \%$ exhibit a low degree of rounding (Fig. 6C); 60\% of bioclasts have abrasion with a high degree of damage (Fig. 6D); 56\% of the bioclasts have a low degree of preserved microarchitecture (Fig. 6E); $70 \%$ of the beds that compose the interval have shells with concave-up orientation and 5\% are of convexity-up (Fig. 6F).
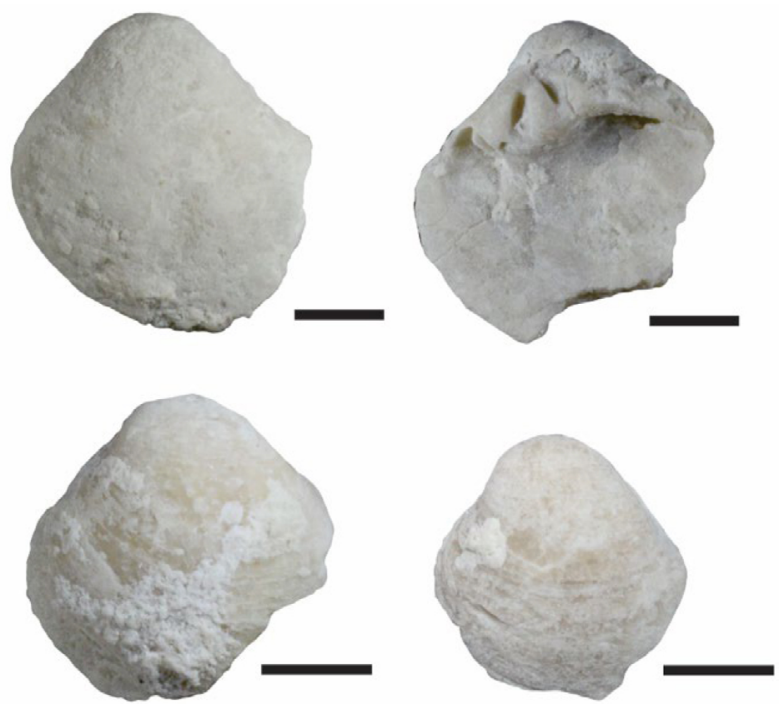

Figure 5. Specimens of Superfamily Crassatelloidea found in Morro do Chaves Formation. Scale bar $5 \mathrm{~mm}$.

\section{Bioerosion}

Bioerosion refers to all destruction and removal of mineral or lithic substrate by the direct action of organisms (Neumann 1966) and is considered to be an important component of meteoric environments (Rehman et al. 1994). The process generates weaknesses in the microarchitecture of shells (Lescinsky et al. 2002), which can promote fragmentation of bioclasts (Oji et al. 2003, Zuschin et al. 2003). Morphological analysis of the recorded bioerosive macrostructures revealed two ichnogenera. These structures were produced most probably by spionid polychaete annelids, Caulostrepsis Clarke, 1908 (see Barrier and D'Alessandro 1985, Wisshak and Neumann, 2006); and carnivorous gastropods Oicnhus Bromley (1981) (see Wisshak et al. 2015).

\section{Ichnotaxonomy}

Ichnofamily OSTEICHNIDAE Höpner \& Bertling, 2017

Caulostrepsis Clarke, 1908

Figs. 7A, 7B, and 7C

Description. Cylindrical borings, somewhat sinuous, unbranched, having unique or U-shaped galleries, with limbs connected by a vane. Some specimens exhibit the aperture apparently in an 8-shape, however eroded to different degrees. The borings ranges are $1 \mathrm{~mm}$ wide and at least $6 \mathrm{~mm}$ long.

Ichnofamily OICHNIDAE Wisshak, Knaust \& Bertling, 2019

Oichnus Bromley (1981)

Figs. 7D and 7E

Description. Elliptical to circular boring through, in a conical shape (gradually the diameter decreases toward the inner part of the valve), with maximum diameter of $1 \mathrm{~mm}$, located in the umbo region of the shell. The ichnotaxonomy of Oicnhus has been discussed by Bromley (1981) and Wisshak et al. (2015).

With images generated using micro-CT scans, it was possible to observe the configuration of the bioerosive macrostructures in the internal part of the shells. One of the specimens showed bioerosion patterns in the form of short tunnels with preserved central wall (Fig. 8).

\section{Micritization}

Micritization is a term introduced by Bathurst (1966), to describe the alteration of the border of the fossil caused by microorganisms, generating fine-grained sediments. The process is very common and affects shells progressively. When micritization is partial, the result is micrite envelopes; if the process continues, the bioclasts can become completely destroyed. Some shells in the studied interval have their lamellar and prismatic microarchitecture preserved, others are completely micritized.

Thin and brownish to opaque envelopes were observed under a microscope in the peripheral part of partly micritized shells, similar to those described by Samankassou et al. (2005). Filaments penetrated perpendicular to the shell surface to a depth of $110 \mu \mathrm{m}$. Pawlowska et al. (2008) showed similar bore patterns in shells colonized by cyanobacteria.

This feature is very delicate, hence very difficult to preserve. For better observation of the microborings, a fluorescent 
A

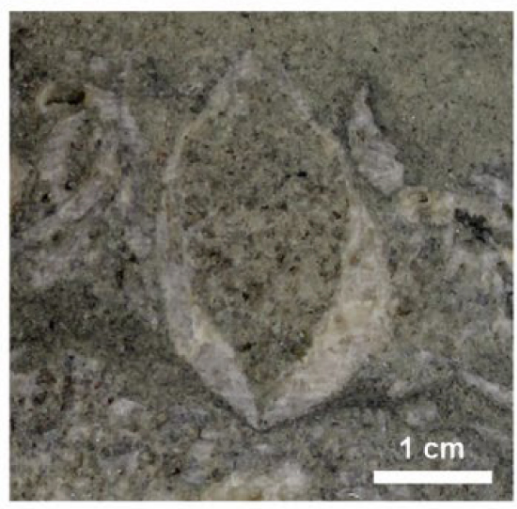

F
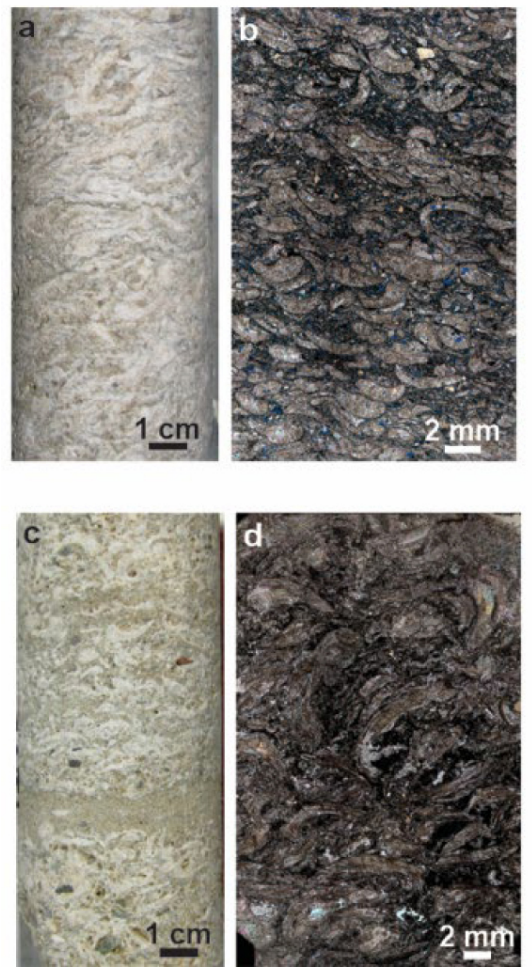

B

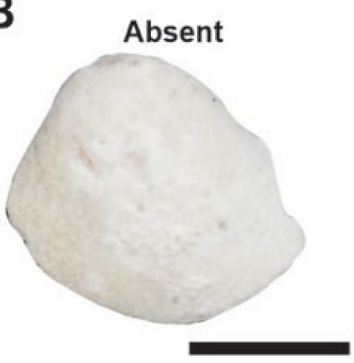

C

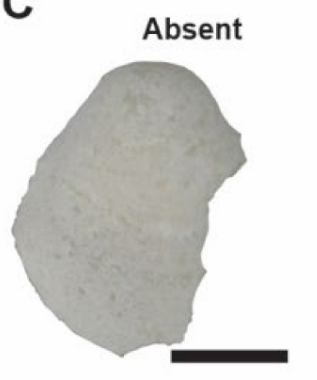

D Absent

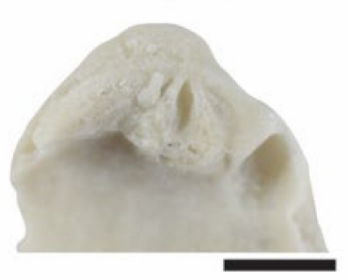

$E$

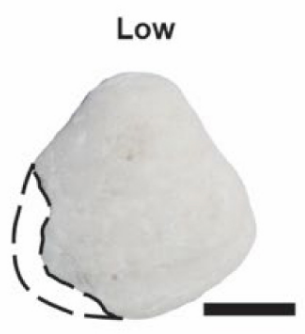

Low

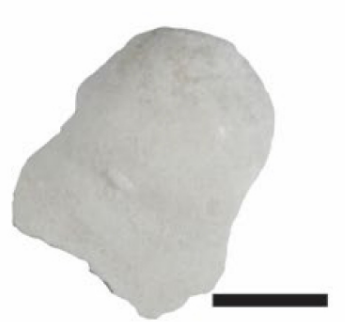

Low
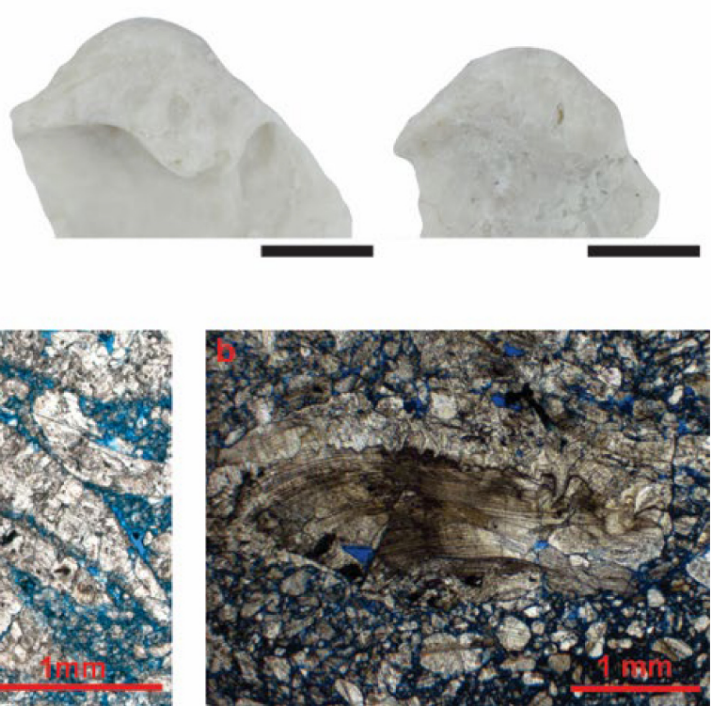

Figure 6. Bioclast showing the taphonomic signatures of the described well core: (A) rare articulated specimen; (B) degree of fragmentation; (C) degree of rounding; (D) intensity of abrasion; (E) whole shell with relic microarchitecture-(a) and fragment with microarchitecture preserved-(b); (F) intervals with shells oriented: concave-up slab from $37.20 \mathrm{~m}$ of depth-(a); thin section from $90.90 \mathrm{~m}$ of depth-(b); convexup slab from $31.70 \mathrm{~m}$ of depth-(c); thin section from $105.95 \mathrm{~m}$ of depth-(d). Scale bar $5 \mathrm{~mm}$.
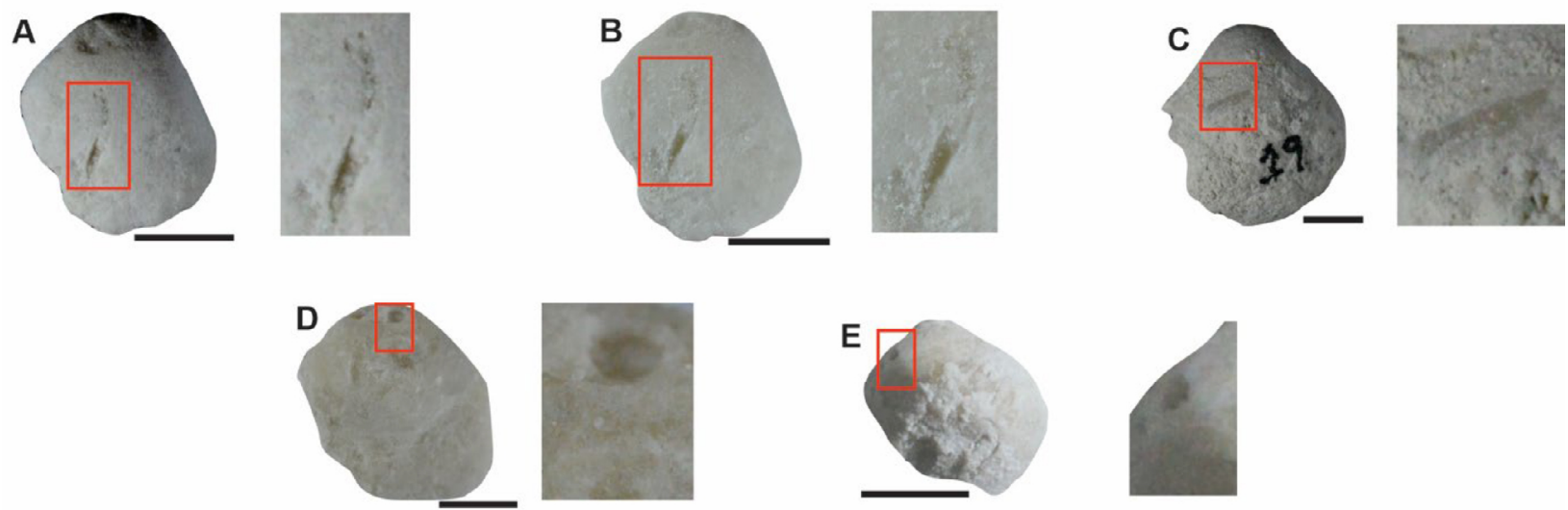

Figure 7. Bioclasts with bioerosive macrostructures and magnification of the structures. (A, B and C) Caulostrepsis isp.; (D and E) Oichnus isp. Scale bar $5 \mathrm{~mm}$. 


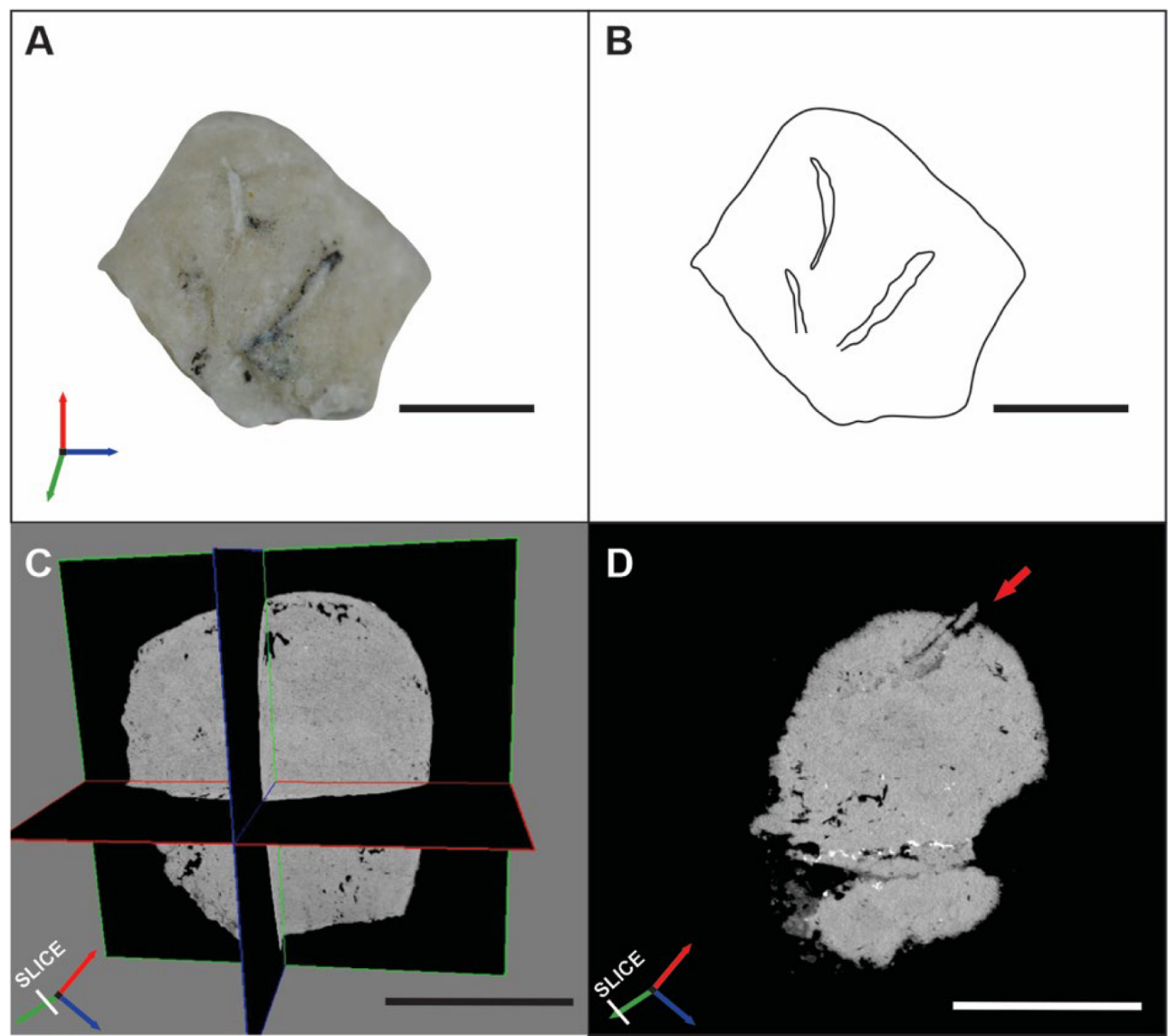

Figure 8. (A) Bioclast with macrobioerosion of Caulostrepsis isp.; (B) schematic representation of the macrobioerosion structure; (C) tridimensional reconstruction of the same shell; (D) slice of tridimensional reconstruction, near the external surface, red arrow shows very prominent macrobioerosion of Caulostrepsis isp. Scale bar $5 \mathrm{~mm}$.

light with different filters was applied, enabling the observation of the micritized border, which has a typical reflectance of organic material (Fig. 9).

The micrite envelopes that occur in the shells of the Morro do Chaves Formation are thin, continuous or discontinuous, with constant or irregular thicknesses (in $\mu \mathrm{m}$ ), showing no preferential orientation, occurring in the peripheral part of the shells.

Different stages of micritization (i.e., partial to complete) were observed on the bioclasts of the Morro do Chaves Formation (Fig. 10):

- Stage I: Micrite occurring superficially, with discontinuous or continuous envelope (occurring throughout the shell), with irregular shapes and maximum thicknesses of a few $\mu \mathrm{m}$. The microarchitecture of shells can be observed;

- Stage II: Micrite envelopes completely formed (occurring throughout the shell), the thickness of up to a few $\mathrm{mm}$. Microarchitecture can be observed in small areas of some shells;
- Stage III: Shells are completely micritized. Microarchitecture is not observed. The shell only remains with its external shape.

The depth interval from 44.80 to $45.80 \mathrm{~m}$ is the interval with the most altered shells (Fig. 11). The base (depth 45.50-45.80 m) is composed of completely micritized bioclasts (Stage III), in conjunction with curved fissures forming nodules (nodulization process). The nodules have curved and irregular borders with generally small sizes ( $\mu \mathrm{m}$ to $\mathrm{mm}$ ). In thin sections, it is possible to observe that some nodules maintain the morphologies and organization of the original shells.

Towards the top, the interval is composed of 60 to $70 \%$ of shells measuring $2 \mathrm{~cm}$ (on average), 20\% siliciclastic matrix, $10 \%$ micrite and intense cementation, low degree of abrasion and rounding. The orientation of the shells alternates in the beds, being concave-up and concave down.

The depth $45.15 \mathrm{~m}$ has a thin level of micritized material with horizontal planar and curved fissures forming nodules, 

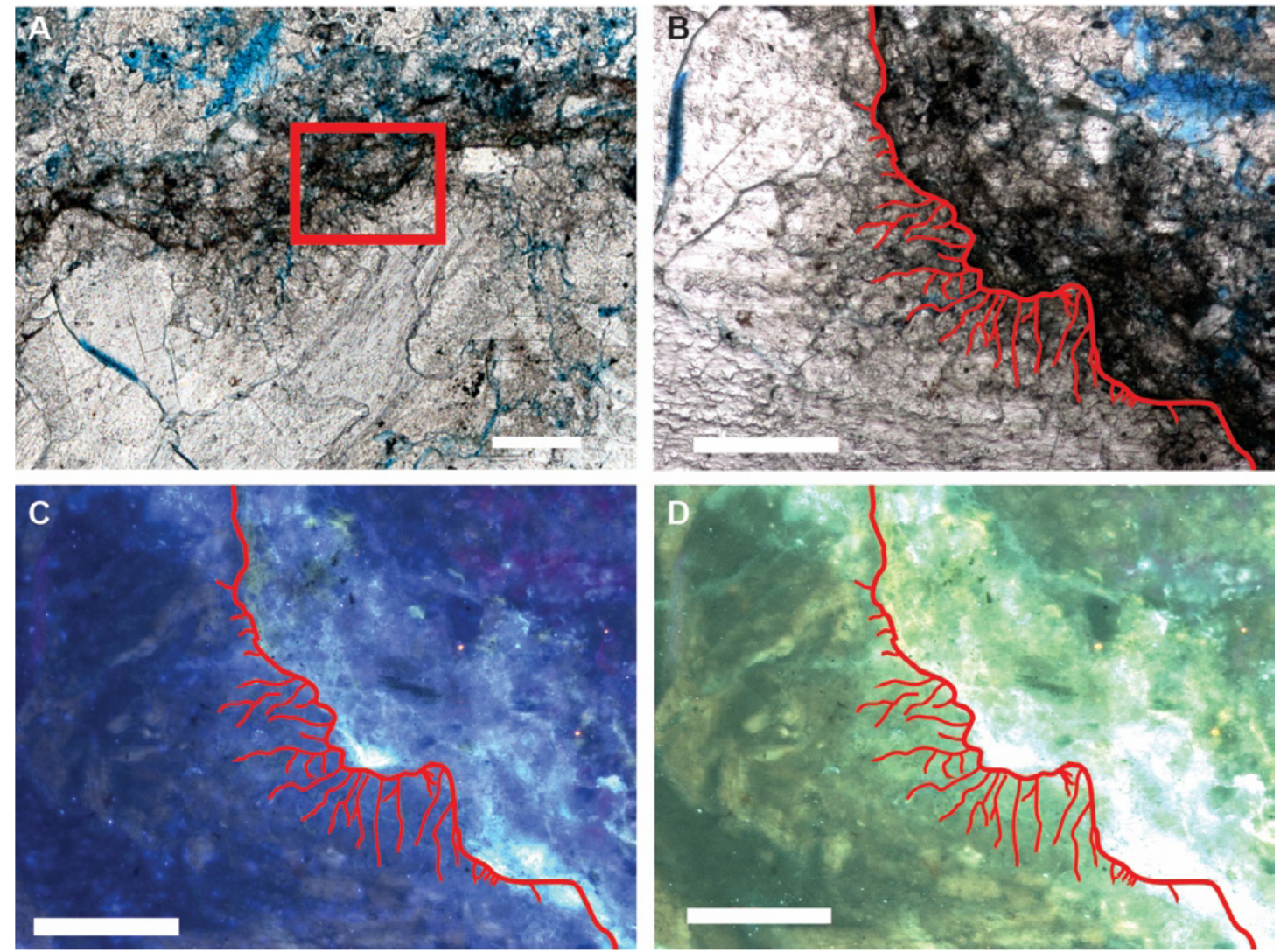

Figure 9. Border of fragmented bioclasts with micrite (sample from $38.20 \mathrm{~m}$ of depth in the well). (A) The red square highlights microborings, which have maximum depth of $110 \mu \mathrm{m}$ (5x magnification); (B) microborings under transmitted light (10x magnification); (C) microborings under incident blue light (fluorescent) with UV filter (10x magnification); (D) microborings under incident blue light with blue filter (10x magnification). Scale bar $200 \mu \mathrm{m}$.

\section{Stage I}
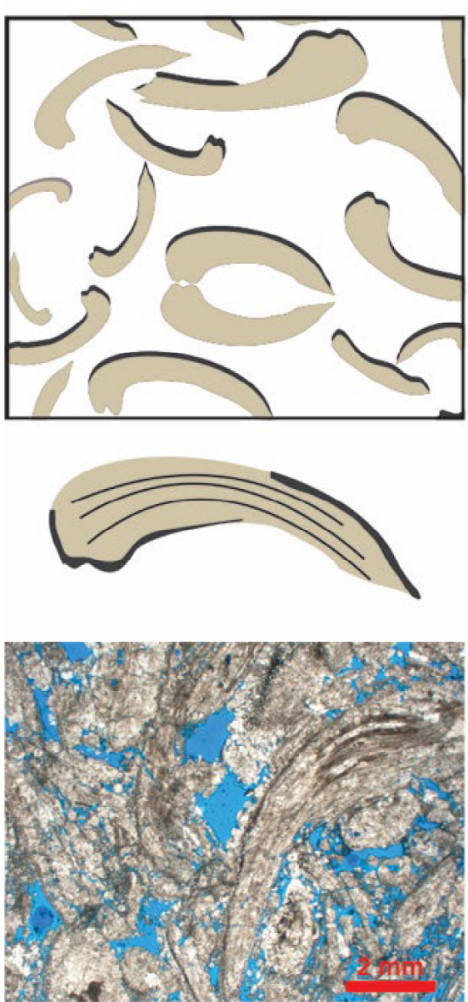

Stage II
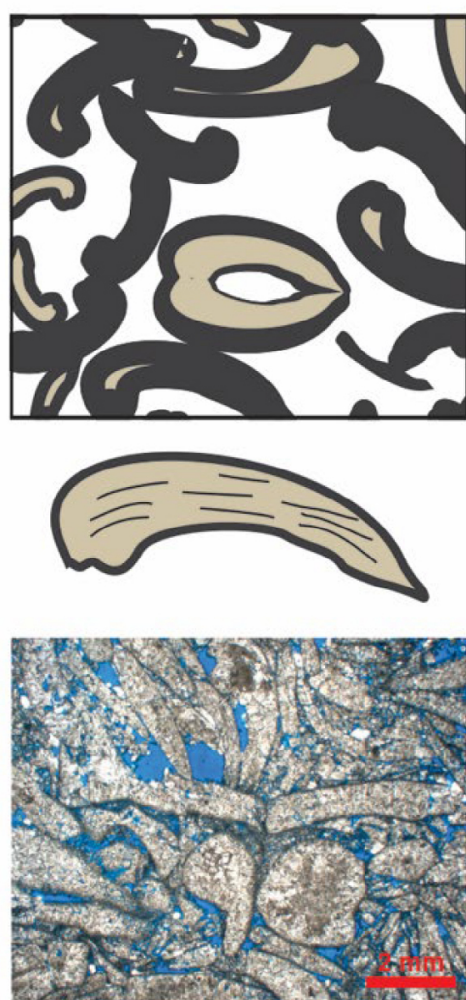

Stage III
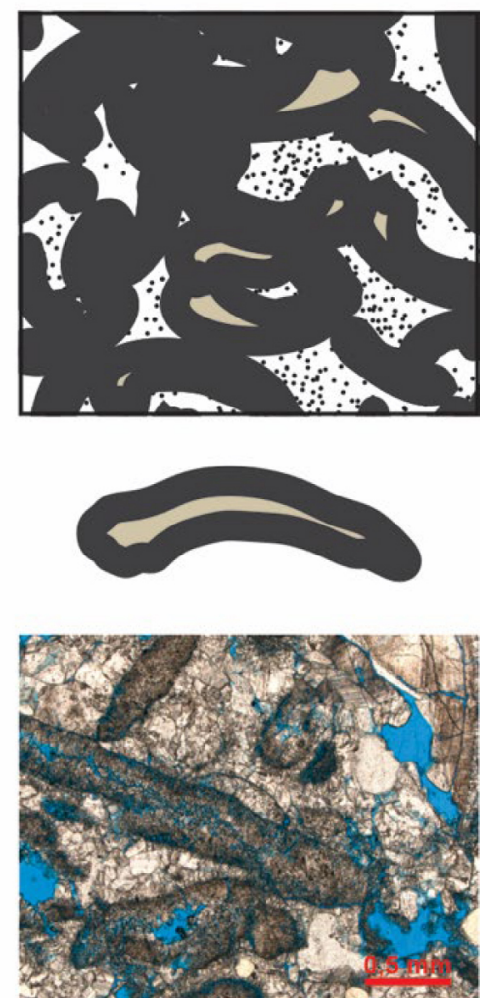

Figure 10. Sketch illustrating micritization pathway of the bioclasts. Stage I is characterized by thin micrite envelopes; Stage II by thick micrite envelopes; Stage III by bioclasts completely micritized. 


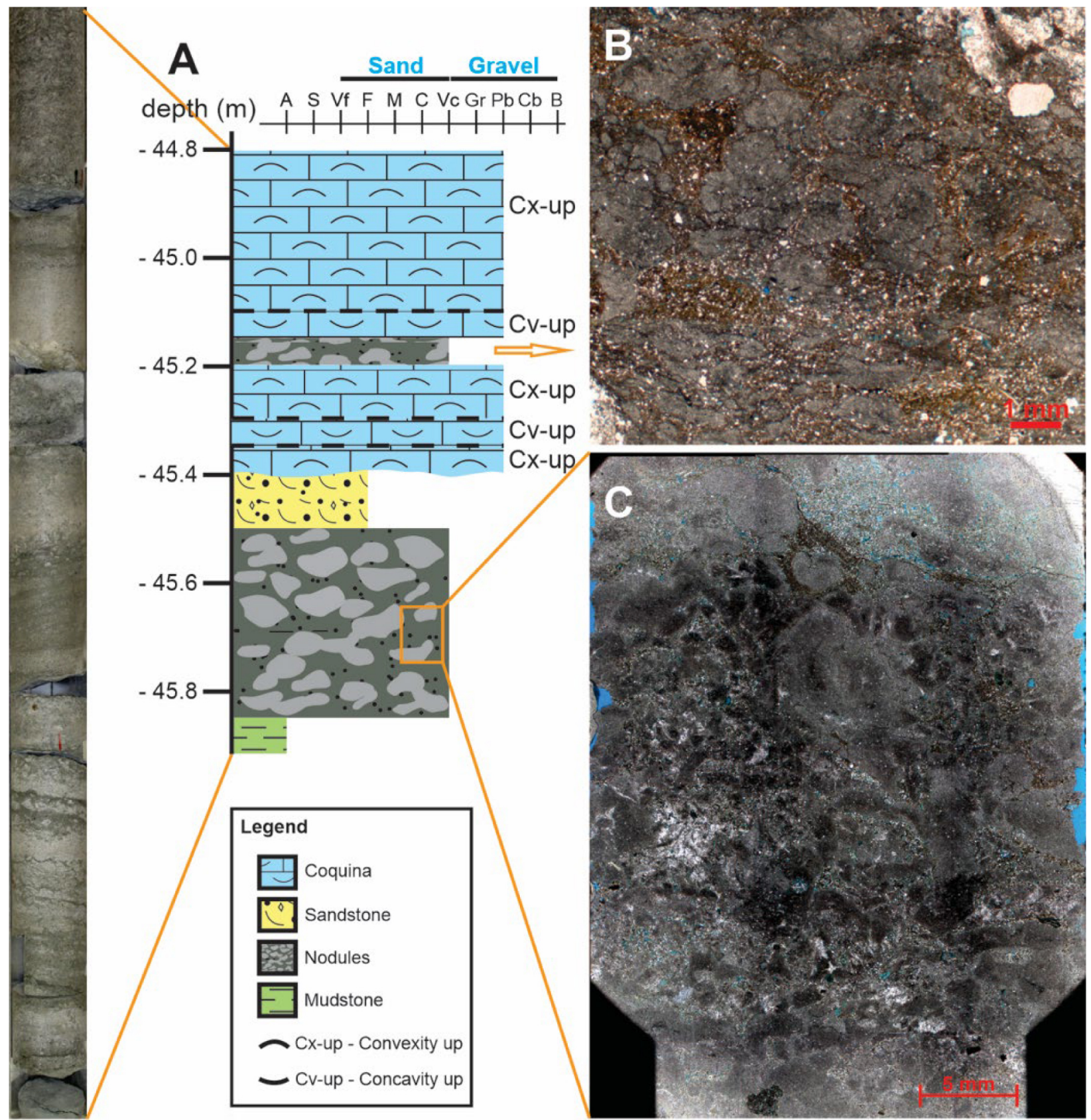

Figure 11. (A) Stratigraphic interval of 44.80-45.80 m and sedimentary log of 1:10 scale of the same interval; (B) photomicrography of thin section of micritized material with planar fissures, filled with siliciclastic material; (C) photomicrography mosaic of the altered shells. 1.25x magnification; crossed polars.

the intersection of curved fissures produces new nodules, $\mu \mathrm{m}$ in size, and the fissures are filled with subangular very finegrained sand and mud (Fig. 11B).

\section{DISCUSSION}

The characteristics of the coquinas interval described in the Morro do Chaves Formation is an intense diagenesis linked to the abundant occurrence of stylolites (in different layers) enables to classify the deposits as mixed sedimentologic-diagenetic origin (Kidwell et al. 1986).

The paleoenviroment for that high concentration of shells should be similar to that proposed by Figueiredo (1981) with beaches and shallow platforms. Tavares et al. (2015) proposed a depositional model for the Morro do Chaves Formation characterized by lake level oscillations with local exposure. The stratigraphic interval from 45.80 to $44.80 \mathrm{~m}$ of depth can represent the periods of low lake level with consequent exposure of the coquina beds to meteoric alteration.

Additionally, sediment influx is increased during the rising of the lake level under humid conditions (Azambuja et al. 1998), interrupting the micritization process and generating the movement of shells by traction resulting in the orientation of shells with upward convexity (Middleton 1967). This could result in the intercalation of the orientation pattern registered in the 44.80-45.20 m interval.

The taxonomy of the bivalve fauna has been studied by Duarte (1936), Borges (1937), and Oliveira (1937) but until now, new data, taxa reviews, systematics and combinations with currently available data remained largely unexplored. 
The specimens are unidentifiable in more terminal levels, for being represented by broken parts mostly. But they provided broad enough characters for inclusion in the superfamily category. Several case studies demonstrated that the occurrence of single taxa or groups of organisms may already indicate a certain environment (e.g., Fürsich 1993, Andrade et al. 2004, Hessel 2005, Wilmsen et al. 2007, Ayoub-Hannaa et al. 2015). Crassatelloids are bivalves' inhabitants of fauna in salinity conditions that vary from brackish to marine (Stilwell 1998, Gardner 2005, Jaitly and Mishra 2009).

The association with Oicnhus isp. and Caulostrepsis isp. ichnofossils are generally formed by marine organisms (Buatois \& Mángano 2011). The presence of bioerosions provides conduits by which reactive meteoric fluids can penetrate the dense shell (Rehman et al. 1994).

Bioclasts show high frequency of individuals with physical alteration (fragmentation, abrasion, and rounding), in a low degree; articulated shells are rare, and not preserved in life position. These attributes indicate that the bioclastic material was reworked, and then, the deposits are interpreted here as a parautochthonous-allochthonous assemblage (Kidwell et al. 1986).

Mollusk shells are generally extremely resistant to fragmentation, depending on their microarchitecture (Taylor \& Layman 1972), even during eventual transport to a final depositional zone, the shell may not have fragmented. On the other hand, the presence of macrostructures of bioerosion represents a "bioattack" of organisms, which results in the weakening of bioclasts (Verde 2007); with compaction, the material gets fragmented. This could be one of the reasons of causes the fragmentations of bivalves, as opposed to only a result of transport under high-energy conditions. The shells are susceptible to "attack" by organisms, the action of these organisms generates weaknesses in the shells, in addition to the formation of micrite as a consequence of rasping and borings.

The Morro do Chaves Formation registers a very complex diagenetic sequence, due to the overlapping of diagenetic phases. The micritization processes were associated with eogenesis in meteoric environments by Belila (2014) and Tavares et al. (2015). In the present work, the micritization is also interpreted as a process restricted to meteoric environments. Unfortunately, features produced in this environment are too difficult to be recognized in carbonate successions affected by an intense recrystallization process. Reid and Macintyre (2000) pointed out the difficulties to distinguish between infilling of microboring and recrystallization processes, even in thin sections. Despite the poor degree of preservation, is possible to observe features typical of meteoric environments in the described succession, as shown in Figures 9 and 10.

The bioclasts with microborings described in this paper are very similar to those described by Olóriz et al. (2004). These authors interpreted the microboring patterns as produced by fungal and cyanobacterial activity. Tucker and Wright (1991) assigned the process of microbial alteration as a product of meteoric diageneses, thus reinforcing that the features described in this paperwere produced in a meteoric environment.
Kobluk and Risk (1977) studied the micritization process by microbial action and showed this process occurs extremely fast. Endolytic microorganisms started microborings in less than five days and micritic envelopes were formed between 65 and 215 days. According to Radtke and Golubic (2005), borings caused by microorganisms are good indicators of environmental conditions and paleobatimetric estimates, the authors showed the action of cyanobacteria on shells at depths of 1 to $60 \mathrm{~m}$; due to the high diversity of microorganisms up to $15 \mathrm{~m}$ of depth, the activity of microbores in the shells is more intense.

Flügel (2004) proposed the differentiation of the micritization process in two ways: destructive micritization related to microboring organisms, which degrade the material and constructive micritization related to epileptic organisms, with leads to the addition of material. The destructive results in thick and continuous envelopes and is the predominant micritization processes in the coquinas of Morro do Chaves Formation. The destructive processes follow three stages of evolution (Fig. 10). According to Samankassou et al. (2005), partial micritization (i.e., continuous or discontinuous envelopes) makes the shells weaker and more susceptible to physical degradation (e.g., fragmentation and abrasion), additionally, different species have different microarchitectures and mineralogical composition, which influence the resistance of the shells (Maliva and Dickson 1992).

Different preservation degrees of micritized shells occur in Morro do Chaves. In the same beds, shells occur in a partially preserved condition, whereas others are completely micritized (Fig. 12A). The same situation was observed by Samankassou et al. (2005), studying deposits of southern England, interpreted as formed by different compositions and microstructures of shells.

The micritization process occurs in an exposure environment (Flugel 2004); however, the action of microorganisms (e.g., cyanobacteria and fungi) may occur up to $160 \mathrm{~cm}$ deep below the water sediment interface (Erthal and Ritter 2017).

Carbonate nodules were also observed by Chinelatto et al. (2018), interpreted as features of subaerial exposure formed in incipient drained soils. Complex nodules in the $44.80-45.80 \mathrm{~m}$ interval are associated to an emersion of the bioclasts as a function of lake level variation, allowing the action of nodulization processes in the shells (as a result of aggregation of micritized shells) and formed by coalescence of adjacent elementary nodules (Freytet and Plaziat 1982) (Fig. 12B).

Praça (1996) studied the coquinas of the Lagoa Feia Formation of the Campos Basin and suggested a palustrine facies association, with depositional characteristics associated with secondary fabric characterized by nodulization process (very similar to the described nodules in this interval).

Some neomorphized micrite nodules were observed with quartz grains inside of the micritized material, whose grains are similar to the ones found in the matrix, indicating the micritization process occurred at the same time as the input of siliciclastic in the environment (Figs. 12C and 12D). 

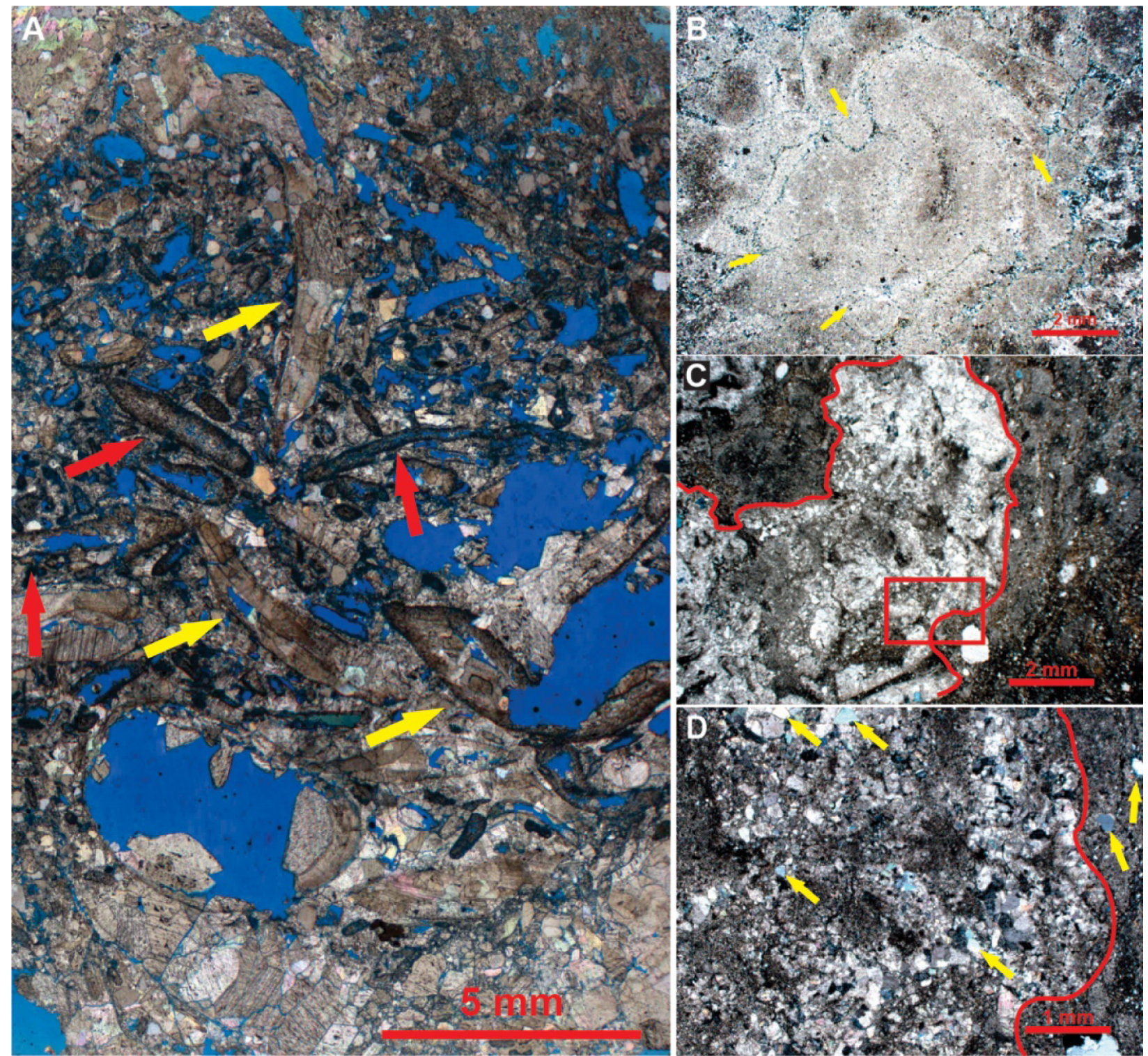

Figure 12. Photomicrographic mosaic of thin section of shells in different stages of micritization. Yellow arrows show well preserved shells and red arrows show completely micritized shells. (A) Blue areas are pore space (33.90 m of depth); (B) complex nodule formed by the coalescence of elementary nodules (45.70 m of depth); (C) photomicrography of neomorphized micrite bioclast (1.25x magnification; parallel polars); (D) yellow arrows indicating grains of quartz inside of neomorphized nodule (2.5x magnification; crossed polars).

\section{CONCLUSIONS}

The studied coquina interval represents a deposit formed by the accumulation of transported bioclasts severely altered by mechanical compaction and cementation that obliterated many of the primary sedimentary and taphonomic features. Furthermore, those features associated with alteration in meteoric environments, which are generally very delicate, are difficult to be observed in the Morro do Chaves Formation. However, an integrated approach developed here enabled the recognition and characterization of many features of meteoric alteration.

The presence of bioerosive marks indicates that the shells were attacked by organisms, which weaken their microstructures and enabled the fragmentation of the shells in an environment of low energy. This process increased the percentage of shell fragments in the system. Moreover, more shell fragments can improve the micritization process due to more contact surfaces.
Micritization is the main process associated to meteoric diagenesis found in the coquina interval of Morro do Chaves Formation. It occurs throughout the studied interval with different degrees of intensity associated to a microbiological destructive activity that can be categorized in three evolutionary stages. The differentiation of the stages results from different periods of changes in lake depth, intensity of microorganism attack, time of alteration and variations in siliciclastic input.

The stratigraphic interval characterized by palustrine facies constitutes a subaerial exposure surface and future correlations with other well cores from Atol quarry and other areas would make it possible to understand its lateral extension and time of exposure. Furthermore, a detailed taxonomic analysis from more samples would also aid to the recognition of the diversity, life habits and paleoecology of bivalves of the Morro do Chaves Formation. 


\section{ACKNOWLEDGMENTS}

The authors would like to express their thanks to Laboratório de Instrumentação Nuclear (LIN) of COPPEUFRJ, for the acquisition of micro-CT images and to Daniel Thompson for his English revision. This research was carried out in association with the $\mathrm{R} \& \mathrm{D}$ projects registered as ANP 18993-6, "Sedimentary geological analysis of Cretaceous carbonate successions in a Brazilian sedimentary basin”
(UFRJ/BG Brasil/ANP), sponsored by BG Brasil and ANP 20225-9, "PRESALT - Geological characterization of carbonate reservoirs from the pre-salt interval of Santos Basin, correlates (Sergipe-Alagoas Basin) and analogues" (UFRJ/Shell Brasil/ANP), sponsored by Shell Brasil, both as part of the "Compromisso com Investimentos em Pesquisa e Desenvolvimento” of ANP. PFD thanks CNPq (process 310164/2017-6) for the research grant.

\section{ARTICLE INFORMATION}

Manuscript ID: 20190072. Received on: 08/14/2019. Approved on: 08/03/2020.

J.P.P.B. conception of the research; wrote the first draft of the manuscript and prepared all figures. P. D. conception of the research; improved the manuscript with corrections and revisions; helped with discussion and suggestions to improve the general organization of the geological data. I.M. taxonomic identification; corrections and suggestion of taphonomic data; revised and improved the manuscript. Competing interests: The authors declare no competing interests.

\section{REFERENCES}

Andrade E.J., Seeling J., Bengtson P., Souza-Lima W. 2004. The bivalve Neithea from the Cretaceous of Brazil. Journal of South American Earth Sciences, 17(1):25-38. https://doi.org/10.1016/j.jsames.2004.05.006

Asmus H.E., Baisch P.R. 1983. Geological Evolution of The Brazilian Continental Margin. Episodes, 6(4):3-9. https://doi.org/10.18814/ epiiugs/1983/v6i4/001

Ayoub-Hannaa W.S., Bengtson P., Fürsich F.T., Andrade E.J. 2015. Cenomanian-Coniacian (Upper Cretaceous) bivalves of the Sergipe Basin, Brazil: Order Pholadomyida. Revista Brasileira de Paleontologia, 18(1):31-70. https://doi.org/10.4072/rbp.2015.1.03

Azambuja N.C., Arienti L.M., Cruz F.E.G. 1998. Guidebook to the Rift-Drift Sergipe-Alagoas, Passive Margin Basin, Brazil. In: AAPG (ed.). The 1998 AAPG International Conference and Exhibition. Rio de Janeiro: AAPG, 113 p.

Barrier P., D’Alessandro A. 1985. Structures biogéniques et physiques dans les sables de Paviliana Reggio Calabria (Italie). Rivista Italiana di Paleontologia e Stratigrafia, 91(3):379-408.

Bathurst R.G.C. 1966. Boring algae, micrite envelopes and lithification of moluscs bioespatoites. Geology, 5(1):15-32. https://doi.org/10.1002/ gj.3350050104

Bathurst R.G.C. 1975. Carbonate sediments and their diagenesis. New York: Elsevier, $658 \mathrm{p}$.

Belila A.M.P. 2014. Caracterização petrofísica dos carbonatos da Formação Morro do Chaves, Bacia de Sergipe-Alagoas. MSc Dissertation, Instituto de Geociências, Universidade Estadual de Campinas, Campinas, 58 p.

Best M.M.R., Kidwell S.M. 2000. Bivalve taphonomy in tropical mixed siliciclastic-carbonate settings: I. Environmental variation in shell condition. Paleobiology, 26(1):80-102. https://doi. org/10.1666/0094-8373(2000)026\%3C0080:BTITMS\%3E2.0.CO;2

Borges J. 1937. Pesquisas de Fósseis em Jaboatão e Morro do Chaves, Brasil: notas preliminares e estudos. Serviço Geológico e Mineralógico, 15:7-11.

Bromley R.G. 1981. Concepts in ichnotaxonomy illustrated by small round holes in shells. Acta Geológica Hispánica, 16(1-2):55-64.

Bromley R.G. 1996. Trace Fossils: Biology, Taphonomy and Applications. $2^{\text {nd }}$ ed. London: Chapman and Hall, $378 \mathrm{p}$.

Buatois L.A., Mángano M.G. 2011. Ichnology: Organism-Substrate Interactions in Space and Time. Cambridge: Cambridge University Press, $350 \mathrm{p}$.

Campos Neto O.P.A., Lima W.S., Cruz F.E.G.C. 2007. Bacia de Sergipe-Alagoas. Boletim de Geociências da Petrobras, 15(2):405-415.

Carter J.G., Altaba C.R., Anderson L.C., Araujo R., Biakov A.S., Bogan A.E., Campbell D.C., Campbell M., Jin-hua C., Cope J.C.W., Delvene G., Dijkstra H.H., Zong-jie F., Gardner R.N., Gavrilova V.A., Goncharova I.A., Harries P.J., Hartman J.H., Hautmann M., Hoeh W.R., Hylleberg J., Bao-yu
J., Johnston P., Kirkendale L., Kleemann K., Koppka J., Křrǐ J., Machado D., Malchus N., Márquez-Aliaga A., Masse J., McRoberts C.A., Middelfart P.U., Mitchell S., Nevesskaja L.A., Özer S., Pojeta Jr. J., Polubotko I.V., Pons J.M., Popov S., Sánchez T., Sartori A.F., Scott R.W., Sey I.I., Signorelli J.H., Silantiev V.V., Skelton P.W., Steuber T., Waterhouse J.B., Wingard G.L., Yancey T. 2011. A synoptical classification of the Bivalvia (Mollusca). University of Kansas Paleontological Contributions, (4):1-47. https://doi. org/10.17161/PC.1808.8287

Carter J.G., Harries P.J., Malchus N., Sartori A.F., Anderson L.C., Bieler R., Bogan A.E., Coan E.V., Cope J.C.W., Cragg S.M., García-March J.R., Hylleberg J., Kelley P., Kleemann K., Křriz J., McRoberts C., Mikkelsen P.M., Pojeta Jr.J., Tëmkin I., Yancey T., Zieritz A. 2012. Treatise Online no. 48: Part N, Revised, Volume 1, Chapter 31: Illustrated Glossary of the Bivalvia. Treatise Online, (30-56):1-209. https://doi.org/10.17161/ to.v0i0.4322

Castro J.W.A., Senra M.C.E., Ramos R.R.C. 2009. Coquinas da Paleolaguna da Reserva Tauá - Pântano da Malhada, RJ. In: Winge M., Schobbenhaus C., Souza C.R.G., Fernandes A.C.S., Berbert-Born M., Queiroz E.T. (eds.). Sitios Geológicos e Paleontológicos do Brasil. $2^{\text {nd }}$ ed. Brasília: CPRM, p. 269-276.

Chinelatto G.F., Vidal A.C., Kuroda M.C., Basilici G. 2018. A taphofacies model for coquina sedimentation in Lakes (Lower Cretaceous, Morro do Chaves Formation, NE Brazil). Cretaceous Research, 85:1-19. https://doi. org/10.1016/j.cretres.2017.12.005

Davies D.J., Powell E.N., Stanton Jr. R.J. 1989. Taphonomic signatures as a function of environmental process: shells and shell beds in hurricane-influenced inlet on the Texas coast. Palaeogeography, Palaeoclimatology, Palaeoecology, 72:317-356. https://doi. org/10.1016/0031-0182(89)90150-8

Duarte A.G. 1936. Edade dos Calcareos do Morro do Chaves, Estado de Sergipe Boletim do Serviço Geológico e Mineralógico, 79:1-15.

Erthal F., Ritter M.N. 2017. Tafonomia atualística. In: Horodyski R.S., Erthal F. (eds.). Tafonomia: métodos, processos e aplicação. Curitiba: CRV, p. 29-80.

Feijó F.J. 1994. Bacias de Sergipe e Alagoas. Boletim de Geociências da Petrobras, 8(1):149-160

Figueiredo A.M.F. 1981. Depositional systems in the lower Cretaceous Morro do Chaves and Coqueiro Seco Formations, and their relationship to petroleum accumulations, middle rift sequence, Sergipe-Alagoas Basin, Brazil. PhD Thesis, University of Texas, Austin, $275 \mathrm{p}$.

Flügel E. 2004. Microfacies of Carbonate Rocks. Analysis, Interpretation and application. New York: Elsevier; Berlin / Heidelberg: Springer, 976 p.

Freytet P., Plaziat J.C. 1982. Continental carbonate sedimentation and pedogenesis - Late Cretaceous and Early Tertiary of Southern France. In: Füchtbauer H., Lisitzyn A.P., Milliman J.D., Seibold E. (eds.). Contributions to Sedimentology. Stuttgart: Schweizerbart Science Publishers, $217 \mathrm{p}$. 
Fürsich F.T. 1993. Palaeoecology and evolution of Mesozoic salinitycontrolled benthic macroinvertebrate associations. Lethaia, 26(4):327-346. https://doi.org/10.1111/j.1502-3931.1993.tb01540.x

Fürsich F.T., Pandey D.K. 2003. Sequence stratigraphic significance of sedimentary cycles and shell concentrations in the Upper Jurassic-Lower Cretaceous of Kachchh, western India. Palaeogeography, Palaeoclimatology, Palaeoecology, 193(2):285-309. https://doi.org/10.1016/S0031-0182(03)00233-5

Gardner R.N. 2005. Middle-Late Jurassic bivalves of the superfamily Veneroidea from New Zealand and New Caledonia. New Zealand Journal of Geology and Geophysics, 48(2):325-376. https://doi.org/10.1080/002883 06.2005.9515119

Hessel M.H. 2005. Anditrigonia britoi n.sp. (Bivalvia) do eo-albiano de Sergipe, Brasil. Arquivos do Museu Nacional, 63(3):437-450.

Jaitly A.K., Mishra S.K. 2009. Campanian-Maastricthian (Late Cretaceous) veneroids (Bivalvia: Heterodonta) from the Ariyalur Group, South India. Palaeoworld, 18(4):251-262. https://doi.org/10.1016/j.palwor.2009.09.001

Kidwell S.M., Fürsich F.T., Aigner T. 1986. Conceptual framework for the analysis and classification of fossil concentrations. Palaios, 1(3):228-238. https://doi.org/10.2307/3514687

Kidwell S.M., Holland S.M. 1991. Field description of coarse bioclastic fabrics. Palaios, 6(4):426-434. https://doi.org/10.2307/3514967

Kobluk D.R., Risk M.J. 1977. Calcification of Exposed filaments of Endolithic Algae, Micrite Envelope Formation and Sediment Production. Journal of Sedimentary Petrology, 47(2):517-528. https://doi. org/10.1306/212F71C6-2B24-11D7-8648000102C1865D

Koutsoukos E.A.M., Bengtson P. 1993. Towards an Integrated Biostratigraphy of The Upper Aptian-Maastrichtian of The Sergipe Basin, Brazil. Documents des Laboratories de Géologie, (125):241-262.

Koutsoukos E.A.M., Mello M.R.,Azambuja N.C. 1991. Micropalaeontological and geochemical evidence of mid-Cretaceous dysoxic-anoxic palaeoenvironments in the Sergipe Basin, northeastern Brazil. In: Tyson R.S., Pearson T.H. (eds.). Modern and Ancient Continental Self Anoxia. London: Geological Society Special Publication, 58(1), p. 427-447.

Kowalewski M., Flessa K.W., Aggen J.A. 1994. Taphofacies analysis of recent shelly cheniers (Beach Ridges), Northeastern Baja California, Mexico. Facies, 31:209-242. https://doi.org/10.1007/BF02536940

Lana M.C. 1990. Bacia de Sergipe-Alagoas: Uma Hipótese de Evolução Tectono-Sedimentar. In: Gabaglia G.P.R., Milani E.J. (eds.). Origem e Evolução de Bacias Sedimentares. Rio de Janeiro: Gávea, p. 311-332.

Lescinsky H.L., Edinger E., Risk M.J. 2002. Mollusc shell encrustation and bioerosion rates in a modern epeiric sea: taphonomy experiments in the Java Sea, Indonesia. Palaios, 17:171-191. https://doi. org/10.1669/0883-1351(2002)017<0171:MSEABR>2.0.CO;2

Maliva R.G., Dickson J.A.D. 1992. The mechanism of skeletal aragonite neomorphism: evidence from noemorphosed mollusks from the upper Purbeck Formation (Late Jurassic - Early Cretaceous), southern England. Sedimentary Geology, 76(3-4):221-232. https://doi. org/10.1016/0037-0738(92)90085-6

McGlue M.M., Soreghan M.J., Michel E., Todd J.A., Mischler J., O’Connell C.S.; Castañeda O.S., Hartwell R.J., Lezzar K.E., Nkotagu H.H. 2010. Environmental Controls on Shell-Rich Facies in Tropical Lacrustine Rifts: A View from Lake Tanganyika's Littoral. Palaios, 25(7):426-438. http:// dx.doi.org/10.2110/palo.2009.p09-160r

Mello M.R., Koutsoukas E.A.M., Neto E.V.S., Silva-Telles Jr. A.C. 1993. Geochemical and micropaleontological characterization of lacustrine and marine hypersaline environments fromBrazilian sedimentary basins. In: Katz B.J., Pratt L.M. (eds.). Source Rocks in a Sequence Stratigraphic Framework. AAPG Studies in Geology, 37. Tulsa, Oklahoma: AAPG, p. 17-34.

Middleton G.V. 1967. The orientation of concavo-convex particles deposited from experimental turbidity currents. Journal of Sedimentary Petrology, 37(1):229-232. https://doi. org/10.1306/74D716A4-2B21-11D7-8648000102C1865D

Muniz M.C. 2013. Tectono-Stratigraphic evolution of the Barremian-Aptian Continental Rift Carbonates in Southern Campos Basin, Brazil. PhD Thesis, Royal Holloway University of London, London, $301 \mathrm{p}$.

Munsell. 2009. Munsell soil color charts: with genuine Munsell color chips. Grand Rapids, Michigan: X-rite.
Neumann A.C. 1966. Observations on coastal erosion in Bermuda and measurements of the boring rate of the sponge Cliona lampa. Lymnology and Oceannography, 11(1):92-108. https://doi.org/10.4319/lo.1966.11.1.0092

Neves J.P., Rohn R., Simões M.G. 2010. Tafonomia de Biválvios em Calcários Oolíticos da Formação Teresina (Bacia do Paraná, Permiano Médio, Prudentópolis, PR). Geologia USP. Série Científica, 10(3):19-36. https://doi.org/10.5327/Z1519-874X2010000300002

Oji T., Ogaya C., Sato T. 2003. Increase of shell-crushing predation recorded in fossil shell fragmentation. Paleobiology, 29(4):520-526. https://doi. org/10.1666/0094-8373(2003)029\%3C0520:IOSPRI\%3E2.0.CO;2

Oliveira P.E. 1937. Fósseis de Propriá e Jaboatão, Estado de Sergipe: Notas preliminares e estudos. Serviço Geológico e Mineralógico, 15:11-16.

Olóriz F., Reolid M., Rodríguez-Tovar F.J. 2004. Microboring and taphonomy in Middle Oxfordian to lowermost Kimmeridgian (Upper Jurassic) from the Prebetic Zone (southern Iberia). Palaeogeography, Palaeoclimatology, Palaeoecology, 212(3-4):181-197.https://doi.org/10.1016/j.palaeo.2004.05.022

Pawlowska A.M., Palińska K.A., Piekarek-Jankowska H. 2008. Colonisation and bioerosion of marine bivalve shells from the baltic sea by euendolithic cyanobacteria: an experimental study. In: Wisshak M., Tapanila L. (eds.). Current Developments in Bioerosion. Erlangen Earth Conference Series. Berlin / Heidelberg: Springer-Verlag, p. 109-120.

Playford P.E., Cockbain A.E., Berry P.F., Roberts A.P., Haines P.W., Brooke B.P. (eds.). 2013. The geology of Shark Bay. Perth: Geological Survey of Western Australia, 146, 281 p.

Ponciano L.C.M.O., Fonseca V.M.M., Machado D.M.C. 2012. Taphofacies analysis of late early Givetian fossil assemblages of the Parnaíba Basin (State of Piauí, northeast Brazil). Palaeogeography, Palaeoclimatology, Palaeoecology, 326-328:95-108. https://doi.org/10.1016/j.palaeo.2012.02.008

Porto-Barros J.P., Dal' Bó P.F.F., Fernandes A.C.S., Borghi L. 2017. Caracterização Sedimentar e Tafonômica de Depósitos Bioclásticos na Reserva Tauá e Marina Búzios (Holoceno do Estado do Rio de Janeiro). Anuário do Instituto de Geociências, 40(2):220-233. https://doi. org/10.11137/2017_2_220_233

Praça U.M. 1996. Calcários de águas raras e calcários palustres da Sequência das coquinas, Formação Morro do Chaves. MS Dissertation, Programa de Pós-graduação em Geologia, Instituto de Geociências, Universidade Federal do Rio de Janeiro, Rio de Janeiro, $94 \mathrm{p}$.

Radley J.D., Barker M.J. 2000. Palaeoenvironmental significance of storm coquinas in a Lower Cretaceous coastal lagoonal succession (Vectis Formation, Isle of Wight, Southern England). Geology Magazine, 137(2):193-205. https://doi.org/10.1017/S0016756800003782

Radtke G., Golubic S. 2005. Microborings in mollusk shells, Bay of Safaga, Egypt: Morphometry and ichnology. Facies, 51:118-134. https://doi. org/10.1007/s10347-005-0016-02

Rehman J., Jones B., Hagan T.H., Coniglio M. 1994. The influence of sponge borings on aragonite to calcite inversion in late Pleistocene Strombus gigas from Grand Cayman, British West Indies. Journal of Sedimentary Research, 64(2a):174-179. https://doi.org/10.1306/ D4267D48-2B26-11D7-8648000102C1865D

Reid R.P., Macintyre I.G. 2000. Microboring Versus Recrystallization: Further Insight into The Micritization Process. Journal of Sedimentary Research, 70(1):24-28. http://dx.doi. org/10.1306/2DC408FA-0E47-11D7-8643000102C1865D

Samankassou E., Tresch J., Strasser A. 2005. Origin of peloids in Early Cretaceous deposits, Dorset, South England. Facies, 51:264-274. https:// doi.org/10.1007/s10347-005-0002-8

Schaller H. 1969. Revisão estratigráfica da Bacia Sergipe Alagoas. Boletim Técnico da Petrobras, 12(1):21-86.

Simões M.G., Kowalewski M. 1998. Shell Beds as Paleoecological Puzzles: a Case Study from the Upper Permiano of the Paraná Basin, Brazil. Facies, 38:175-195. https://doi.org/10.1007/BF02537364

Simões M.G., Kowalewski M., Torello F.F., Ghilhardi R.P., Mello L.H.C. 2000. Early onset of modern-style shell beds in the Permian sequences of the Paraná Basin: Inplications for the Phanerozoic trend in bioclastic accumulation. Revista Brasileira de Geociências, 30(3):499-503.

Stilwell J.D. 1998. Late Cretaceous Mollusca from the Chatham Islands, New Zealand.Alcheringa,22(1):29-85.https://doi.org/10.1080/03115519808619238 
Tavares A.C., Borghi L., Corbett P., Nobre-Lopes J., Câmara R. 2015. Facies and depositional environments for the coquinas of the Morro do Chaves Formation, Sergipe-Alagoas Basin. Brazilian Journal of Geology, 45(3):415-429. http://dx.doi.org/10.1590/2317-488920150030211

Taylor J.D., Layman M. 1972. The mechanical properties of Bivalve (Mollusca) Shell Structures. Palaeontology, 15(1):73-87.

Thompson D.L., Stilwell J.D., Hall M. 2015. Lacustrine carbonate reservoirs from Early Cretaceous rift lakes of Western Gondwana: Pre-Salt coquinas of Brazil and West Africa. Gondwana Research, 28(1):26-51. https://doi. org/10.1016/j.gr.2014.12.005

Tucker M.E., Wright V.P. 1991. Carbonate Sedimentology. New York: Blackwell Science, $482 \mathrm{p}$.

Verde M. 2007. Bioerosão. In: Carvalho I.S., Fernandes A.C.S. (eds.) Icnologia. São Paulo: Sociedade Brasileira de Geologia, 3, p. 108-117.

Walker R.G. 2006. Facies models revisited: introduction. In: Posamentier H.W., Walker R.G. (eds.). Facies Models Revisited. Canada: Society for
Sedimentary Geology, Special Publication, Geological Association of Canada, 84, p. 1-19.

Wilmsen M., Niebuhr B., Wood C.J., Zawischa D. 2007. Fauna and palaeoecology of the Middle Cenomanian Praeactinocamax primus Event at the type locality, Wunstorf quarry, northern Germany. Cretaceous Research, 28(3):428-460. https://doi.org/10.1016/j.cretres.2006.07.004

Wisshak M., Kroh A., Bertling M., Knaust D., Nielsen J.K., Jagt J.W.M., Neumann C., Nielsen K.S.S. 2015. In defence of an iconic Ichnogenus Oichnus Bromley, 1981. Annales Societatis Geologorum Poloniae, 85:445-451. http://dx.doi.org/10.14241/asgp.2015.029

Wisshak M., Neumann C. 2006. A symbiotic association of a boring polychaete and an echinoid from the Late Cretaceous of Germany. Acta Palaeontologica Polonica, 51:589-597.

Zuschin M., Stachowitsch M., Stanton Jr. R.J. 2003. Patterns and processes of shell fragmentation in modern and ancient marine environments. Earth-Science Reviews, 63(1-2):33-82. https://doi.org/10.1016/ S0012-8252(03)00014-X 